Article

\title{
Bactericidal Properties of Copper-Tin Nanoparticles on Escherichia coli in a Liquid Environment
}

\author{
Mohammad Rezayat ${ }^{1,2, *}$ (D), Morteza Saghafi Yazdi ${ }^{1}$, Mohammad Talafi Noghani ${ }^{1}$ and \\ Reza Ahmadi ${ }^{1}$ \\ 1 Department of Materials Science and Engineering, Faculty of Engineering, Imam Khomeini International \\ University, Qazvin 34149, Iran; Msaghafi@eng.ikiu.ac.edu (M.S.Y.); Noghani@eng.ikiu.ac.ir (M.T.N.); \\ Re.ahmadi@eng.ikiu.ac.ir (R.A.) \\ 2 Department of Materials Science and Engineering, Universitat Politècnica de Catalunya, 08034 Barcelona, Spain \\ * Correspondence: Mohammad.Rezayat@upc.edu
}

Received: 27 July 2020; Accepted: 17 August 2020; Published: 1 September 2020

\begin{abstract}
In this research, copper-tin alloy nanoparticles were made by a mechanical alloying method and were examined by two well-known and common bactericidal tests, optical density, and colony-forming units count in terms of bactericidal properties. To confirm the results, two different percentages were used as $\mathrm{Sn}-50 \mathrm{Cu}$ and $\mathrm{Sn}-83 \mathrm{Cu}$, and standard amounts of these alloys were added to the Escherichia coli bacterial culture medium. The results of optical density show that with the addition of more values to the culture medium for bacteria, witnessing the destruction of bacteria, and also the results of colony counting tests can be seen that the number of colonies has decreased over time, even close to zero, which means the environment is free of bacteria. These standard values were different for both alloys; for the Sn-50Cu alloy, the maximum value was $4.5 \mathrm{mg}$, and for the $\mathrm{Sn}-83 \mathrm{Cu}$ alloy, it was $2.75 \mathrm{mg}$, which did not make any difference with the addition of these nanoparticles to the bacterial culture medium.
\end{abstract}

Keywords: nanoparticles; antibacterial; mechanical alloying; optical density; Escherichia coli

\section{Introduction}

The belief that nanotechnology is another age of science and a combination of engineering and biology, chemistry, medicine, and physics has been accepted by the general public. Studies [1-3] have shown that the smaller the nanoparticles, the newer and more different the features and activities. These features have led to the rapid spread of nanomaterials today, so that they can be used in all aspects of life, such as electrical systems, fighting microbes, diagnosing, and treating diseases [1]. It should be noted that nanoparticles have long been discussed in both metal and non-metallic parts. Metal nanoparticles have been used in insecticides and bacteria for many years. Some nanoparticles are considered to be an emerging method in the advancement of modern pharmaceutical science, which, due to their high potential for specific treatment processes, is widely used in biology and pharmaceutical studies: for example, they can kill 650 cancer cells in less than $4 \mathrm{~h}$ [2]. Nanoparticles in the life cycle and ecosystem have shown the lowest levels of toxicity, so using these substances to fight pathogenic microbes can be a good choice. Metal oxide nanoparticles have different antibacterial properties depending on the surface-to-volume ratio. Gram-positive bacteria are more resistant to negative nanoparticles than gram-negative bacteria, which may be related to cell wall structure [3].

Numerous studies have been conducted based on possible reactions between nanoparticles and macromolecules of living organisms. The difference between the negative charge of the microorganism and the positive charge of the nanoparticle acts as an electromagnetic absorber between the microbe and the nanoparticle and binds the nanoparticle to the cell surface and can thus cause cell death [4]. 
They lead to the oxidation of microbial surface molecules and their rapid death. Ions released from nanomaterials may react with thiol (-SH) groups of surface proteins of bacterial cells. A number of these membrane proteins of bacterial cells are responsible for transporting minerals from the surface of the wall, the nanoparticles, by acting on these proteins, inactivate the membrane and make the membrane-impermeable [5]. Nanocides also delay the adhesion of bacterial cells and the formation of biofilms, which prevents a group of bacteria from stabilizing and replicating antimicrobial changes that cause bacterial growth [6]. In this research, a desirable goal is accounted for several factors that can cause infections. Colon formation, bacterial cell growth, and the formation of microbial compressed biofilm matrixes make bacteria resistant to the host defense system, which prevents nanoparticles from forming these microbial defense factors against the host immune system [7]. Nanomaterials, which are based on metal ions, have extensive cellular activity against bacteria, fungi, and viruses. Nanomaterials, especially metallic nanomaterials, due to their surface charge and surface-to-volume ratio, enzymes, and DNA microorganisms with electron balance between electron donor groups such as thiol, carboxylate, amide, imidazole, endow, and hydroxyls are inactive [8].

Nosocomial Infections: In general, nosocomial infections are infections that did not occur at the time of admission by the patient through various growths and are therefore referred to as acquired nosocomial infections. After $72 \mathrm{~h}$, these infections become endemic or epidemic, leading to high mortality and increased costs. The rate of these infections in the ICU is up to 10 times higher than the prevalence of infections in other areas and, bacterial infections (mainly bacteria) occur [9]. Nosocomial infection can affect any organ, but the urinary tract, surgical wounds, and lower parts of the respiratory system are more affected than other organs, and for many years the organ remains in trouble (Table 1).

Table 1. Relative prevalence of nosocomial infections by location. Represented [9].

\begin{tabular}{cc}
\hline Percentage. & Location \\
\hline 38 & Urinary tract \\
18 & The Surgical wounds \\
22 & The lower part of the respiratory system \\
8 & Blood flow \\
14 & Remain parts \\
\hline
\end{tabular}

Antibiotic-resistant organisms are one of the reasons for the increase in nosocomial infections, so controlling these infections should not be based solely on diagnosis, but on determining the type of pathogen responsible and its sensitivity to antibiotics, and different ones are also important [10].

Pharmaceutical resistance: since the recognition of bacteria, humans have always sought to find an effective drug against the infections caused by them, and bacteria are effective mechanisms for the elimination of antibiotics, and they succeeded. Today, with the emergence of drug resistance among the bacteria of the disease, the treatment of this group of infectious diseases has faced many problems [11].

One of the mechanisms of antibiotic resistance is resistance due to chromosomal mutations, which also occurs in the absence of antibiotics. Antibiotic use destroys sensitive strains and selects strains, and becomes resistant. The second mechanism of antibiotic resistance is resistance to genetic exchange, which is often caused by plasmids. These extrachromosomal resistance factors in gram-negative bacteria are called the R-factor. It has been reported to be resistant to streptomycin, neomycin, kanamycin, chloramphenicol, tetracycline, and furazolidone, as well as sulfonamides, which are plasmids that transmit this type of resistance to various bacteria. Antibiotics have been used to treat infections for more than 50 years. During this time, many changes have taken place in the type of antibiotics used, as well as the susceptibility and resistance of bacteria to them [12].

Following the development of antibiotic-resistant organisms, witnessing numerous reports today of their widespread use in various departments of hospitals, often due to the use of broad-spectrum beta-lactam drugs. The prolonged hospitalization of patients and the use of devices such as urinary and intravascular catheters are other factors that increase the pattern of drug resistance in the hospital [13]. 
Unfortunately, with increasing resistance of bacteria to stronger antibiotics, the risk of disease increases in infections threatening human lives. The use of metal oxide nanoparticles to fight bacterial infections can be effective as an alternative to antibiotics. Today, various methods have been used to help humans reduce their use of these antibiotics. Nanoparticles inhibit bacteria without increasing drug resistance [14].

\section{Materials and Methods}

In this study, first nanoparticles were prepared and then their effect on different pathogens $(5,10$, 50 , and $100 \mathrm{ppm}$ ) was investigated for optical density (OD) test, and, (1.5, 1.75, 2.5, 2.75, and 4.5) $\mathrm{mg}$ was examined to count colony forming units test (CFU).

\subsection{Preparation of Nanoparticles}

Nanoparticles were first synthesized by using mechanical alloying with a planetary ball mill. To check the size of the nanoparticles, a Scanning Electron Microscopy (SEM) image was taken with the to confirm the size of the nanoparticles. To distribute the nanoparticles in the growth medium, the nanoparticle solution was placed on the shaker before consumption and after inoculation, it was growth in the grooved incubator. Furthermore, the number of nanoparticles inoculated was not large enough to deposit or have a uniform distribution.

(1) The aroma of nanoparticles used in this study: $\mathrm{CuO}: 90 \mathrm{~nm}$, and $\mathrm{SnO}_{2}: 80 \mathrm{~nm}$

(2) Cultivation environment: from the complex environment complex LB (Lauria Bertani) for growth and control environment and bacterial storage was used.

(3) Pathogenic bacteria studied: in this study, the standard strain was used: Escherichia Coli.

Synthesis of copper-tin nanoparticles: to produce this nanoparticle, 7.56 grams of copper oxide and 14.46 grams of tin oxide along with 2.41 grams of graphite were poured into a planetary mill and mixed and milled after $30 \mathrm{~h}$. They were then placed in a furnace at a temperature of about $1000{ }^{\circ} \mathrm{C}$, and the regeneration operation was carried out entirely under argon gas. After the operation, the presence of nanometer dimensions was confirmed using Transmission Electron Microscopy (TEM) and SEM images.

Effect of different concentrations of nanoparticles on bacteria in the environment: First the growth medium (LB) was synthesized and sterilized, then nanoparticles were added by scales. The powder was weighed, and by adding these particles to $10 \mathrm{ml}$ of liquid growth medium (LB), concentrations of 5 , 10, 50, and 100 of copper-tin nanoparticles. Again, to sterilize the environment for 15 min at $121^{\circ} \mathrm{C}$ and a pressure of $15 \mathrm{lb}$., it was placed in an automatic autoclave and then kept in the refrigerator to cool.

\subsubsection{Metal Powders and Surfactant}

The copper oxide used in this study has a purity of $99.3 \%$ and a particle size of about $100 \mu \mathrm{m}$, which is the product of the Pouyan Chemical Institute. The tin oxide used has a purity of $99.6 \%$ and a particle size of about $80 \mu \mathrm{m}$. A mixture of polyethylene glycol and graphite to facilitate milling and regeneration operations as a surfactant is a pre-milled type with a purity of $99.2 \%$ and a particle size of fewer than $5 \mu \mathrm{m}$ by Fluka. Graphite ensures that in addition to reducing the chemical reaction more easily, fine dust particles do not stick together and that the milling operation is easier and of higher quality [15]. Alloys with different percentages of both elements are produced as can be seen in Table 1. These specific alloy percentages were selected after studying the scientists' research [16,17].

According to thermodynamic analysis and regenerative reaction, the amount of material is measured according to Equation (1).

$$
\mathrm{SnO}_{2}+\mathrm{CuO}+1.5 \mathrm{C} \rightarrow \mathrm{Sn}-\mathrm{Cu}+1.5 \mathrm{CO}_{2} \Delta \mathrm{G}_{298}=54.1 \mathrm{KJ} / \mathrm{mol} ., \Delta \mathrm{H}_{298}=144.6 \mathrm{KJ} / \mathrm{mol}
$$

After balancing and solving the equations, the exact amounts of powders are obtained to start the mechanical milling process, which is shown in Table 2. 
Table 2. Copper and Tin percentage in alloys.

\begin{tabular}{cccccc}
\hline Samples & Copper (\%) & Tin (\%) & Surfactant $\mathbf{( w t} \%)$ & Purity (\%) & Initiation Particles Size $(\boldsymbol{\mu m})$ \\
\hline Cu-Sn35 MA & 35 & 65 & 2 & 99.6 & 60 \\
Cu-Sn50 MA & 50 & 50 & 2 & 99.5 & 70 \\
Cu-Sn83 MA & 83 & 17 & 2 & 99.3 & 80 \\
\hline
\end{tabular}

\subsubsection{High-Energy Ball Milling}

The milling process was carried out by a planetary ball mill, which is a type of high-energy mill. The device used is the planetary mill (PM) 2400 with two milling chambers.

To start the milling operation, As can be seen in Equations (1-3), $7.56 \mathrm{gr}$ of copper oxide, $14.46 \mathrm{gr}$ of tin oxide, and $2.41 \mathrm{gr}$ of graphite were measured with a balance of 4 zeros. A mixture of copper oxide powders and tin oxides with $40 \%$ excess graphite (to achieve oxide, carbide, alloying and structure samples) as raw materials in a high-energy planetary ball mill with a chamber and bullets with two diameters of 9 and $14 \mathrm{~mm}$ hardened chromium steels were mechanically machined for $10 \mathrm{~min}, 5,10$, and $30 \mathrm{~h}$ with a powder to bullet ratio of 1 to 20 and a milling speed of $120 \mathrm{rpm}$ under an argon atmosphere, which all parameters that need for producing is showed in Table 3 . The use of oxide powders in micron and millimeter dimensions causes more crushing of powder particles in nanometer dimensions. These milled powder mixtures were produced in different proportions of raw materials, which included $35 \%, 50 \%$, and $83 \%$, copper.

$$
\begin{gathered}
\mathrm{SnO}_{2}+\mathrm{C} \rightarrow \mathrm{Sn}+\mathrm{CO}_{2} \Delta \mathrm{G}_{298}=12.1 \mathrm{KJ} / \mathrm{mol} ., \Delta \mathrm{H}_{298}=184 \mathrm{KJ} / \mathrm{mol} \\
\mathrm{CuO}+\frac{1}{2} \mathrm{C} \rightarrow \mathrm{Cu}+\frac{1}{2} \mathrm{CO}_{2} \Delta \mathrm{G}_{298}=-67.8 \mathrm{KJ} / \mathrm{mol} ., \Delta H=-394.5 \mathrm{KJ} / \mathrm{mol}
\end{gathered}
$$

$\Delta \mathrm{H}_{298}$ enthalpy of reaction formation and $\Delta \mathrm{G}_{298}$ energy of reaction formation.

Table 3. Ball milling parameters.

\begin{tabular}{ccccc}
\hline Balls size (mm) & Number of Balls & Velocity (RPM) & Time (H, Min.) & Ratio \\
\hline \multirow{2}{*}{9} & \multirow{2}{*}{16} & \multirow{2}{*}{120} & $10 \mathrm{Min}$. \\
& \multirow{2}{*}{14} & & $5 \mathrm{H}$ & 20 \\
& 8 & $10 \mathrm{H}$ & \\
\hline
\end{tabular}

\subsubsection{Heat Treatment}

It was decided to use heat treatment after it became clear that milling would not revive the graphite powder mixture in a short time. A mixture of $10 \mathrm{~h}$ milled powder mixture with $40 \%$ excess graphite at was heated at temperatures of 400,700 , and $1000{ }^{\circ} \mathrm{C}$ in an argon atmosphere for $1 \mathrm{~h}$ at a rate of $10{ }^{\circ} \mathrm{C}$ per minute in an alumina boat in a quartz reactor. They were subjected to heat treatment in an induction tube furnace. Finding the temperature required a test, which eventually found the temperatures needed for the heat treatment.

\subsection{Preparation $O D$ and $C F U$ Samples}

A concentration with OD was prepared by a spectral machine at a wavelength of $600 \mathrm{~nm}$, up to a final concentration of $105 \mathrm{cell} / \mathrm{ml}$ of each of the samples to be obtained. In the next step, $2 \mathrm{~mL}$ of the dilution prepared from each of the bacteria was added to the concentrations prepared from (growth medium and nanoparticles) by a sampler of $2 \mathrm{ml}$, and the same steps were used to prepare the control group with the difference that the nanoparticles. The lids of containers containing treatment growth medium (bacteria and nanoparticles) and control growth media were closed and growth in a shaker incubator at $250 \mathrm{rpm}$ at $37^{\circ} \mathrm{C}$ for $24 \mathrm{~h}$. After this time, an optical density of $600 \mathrm{~nm}$ was used to 
measure the concentration of the electrons, and the treatment and positive control and negative control environments were poured into the glass coils for the OD, respectively. The dilution of nanoparticles in the bacterial growth medium was used to calibrate the spectrophotometer as a blank solution.

Mixed cultivation or pour plate is one of the culture methods, it is necessary to prepare a suspension of bacteria, and this means a certain dilution must be prepared from the bacterium in the liquid medium, then $1 \mathrm{cc}$ of it is poured into the bottom of the sterile plate, then the desired culture medium, which has been previously sterilized and its temperature has reached about 45 degrees Celsius, and add $20 \mathrm{CC}$ to the plate, then mix it thoroughly with a circular motion. If it is required to recover the surface of the bacterial environment with a thin layer of the same culture medium, this is also called double-layer culture. After cultivation, different percentages of nanoparticles are made and after one day for each plate, the colonies can be calculated with a colony counting device; after that, the experiment was repeated for each sample and the mean results were reported.

\section{Results and Discussions}

\subsection{X-ray Powder Diffraction (XRD) Pattern}

The X-ray diffraction patterns of the samples were obtained by an XRD device, equipped with a $\mathrm{Cu}_{\mathrm{Ka}}$ beam manufacturer with a voltage of $40 \mathrm{kV}$. In this system, the scattering angle and the speed of the detector count are controlled by the computer, and thus the width and intensity of the peaks can be easily calculated.

Equation (4) shows the Williamson-Hall method that was used to calculate the average strain and the average size of the crystals of the ground powders.

$$
\beta \cos \theta=\frac{0.9 \lambda}{D}+4 \varepsilon \sin \theta
$$

The scattering angle $\theta, D$ is the size of the crystallite, $\lambda$ is the wavelength of $\mathbf{x}$-rays, which is 1.545 angstroms, $\varepsilon$ is the maximum amount of strain in the microstructure of the material. $\beta$ is also considered to be the total scattering of peaks due to the decrease in crystal size and strain in powder particles after milling.

Equation (5) shows the Scherrer method that was used to calculate the average size of crystals of mill powders and then heat treatment due to the release of internal strains.

$$
\beta \cos \theta=\frac{0.9 \lambda}{D}
$$

Figure 1 shows that with the heat treatment of $30 \mathrm{~h}$ assimilated sample at $400{ }^{\circ} \mathrm{C}$, we see a slight reduction in the powder mixture, where there are $\mathrm{CuO}$ and $\mathrm{SnO}_{2}$ phases, and high-intensity peaks appear. At a temperature of $700{ }^{\circ} \mathrm{C}$, the new phase of $\mathrm{Cu}_{2} \mathrm{O}$ was observed. Using Xpert software, the presence of this new phase was confirmed. At this temperature, the intensity of the peaks is very high and the peaks are very high. Regarding the temperature of $1000{ }^{\circ} \mathrm{C}$, it can be said that the Sn-Cu phase has been formed. Regarding the intensity of the peaks, the decrease in the height of the peaks is very significant and the corresponding alloy and $\mathrm{Sn}-\mathrm{Cu}$ phase is fully formed. 


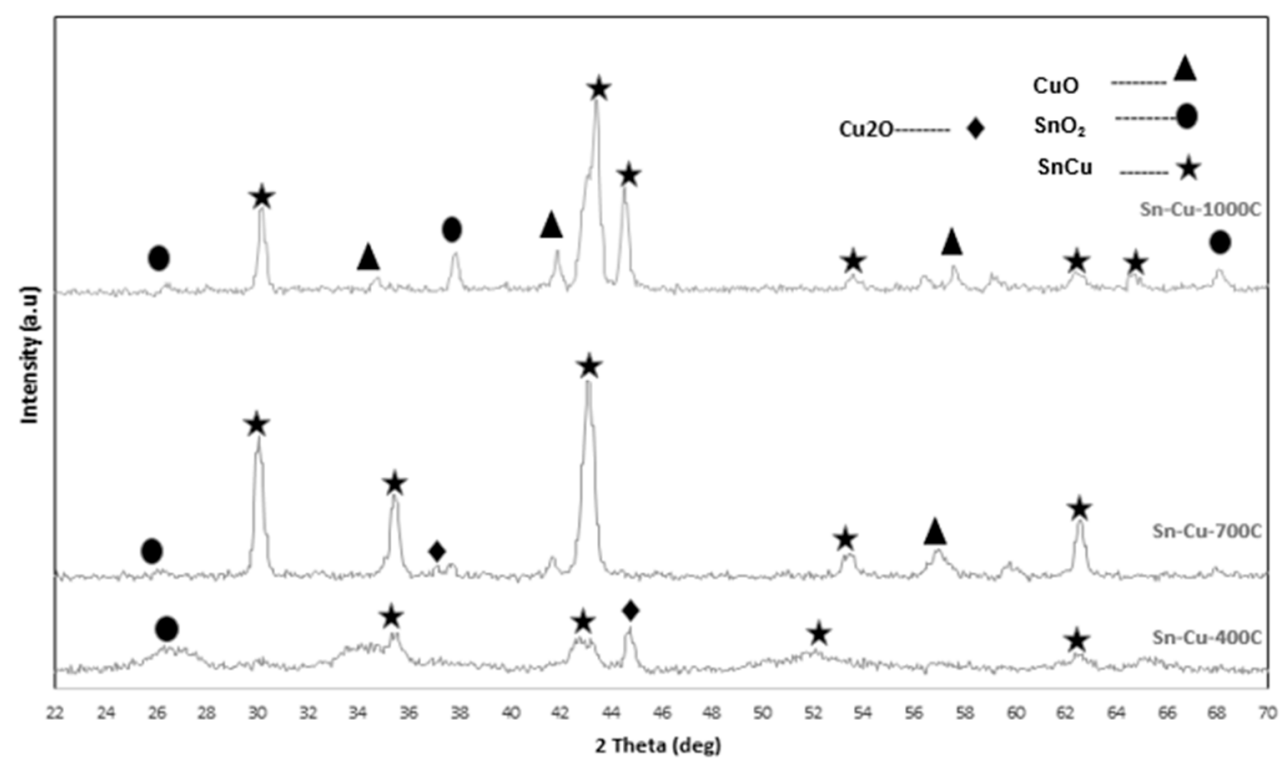

Figure 1. X-ray diffraction patterns for $30 \mathrm{~h}$, and heat treatment to 400,700 , and $1000{ }^{\circ} \mathrm{C}$ for one hour.

\subsection{Differential Thermal Analysis/Thermogravimetry (DTA/TG)}

To investigate the formation process of copper-tin alloy in $10 \mathrm{~min}$ and $10 \mathrm{~h}$ milled sample due to heat treatment, DTA/TG thermal analysis was performed in the temperature range of $25-1000{ }^{\circ} \mathrm{C}$.

From (Figure 2) the two existing thermal differential curves, it can be concluded that with increasing milling time on the curves, it can be seen that the curves are inclined to lower temperatures and the left side of the graph, which can be due to smaller particles; that is, the reduction will take place at lower temperatures. On the other hand, in the diagram related to the sample of $10 \mathrm{~h}$ of milling, the sharp peaks have become flat and smooth peaks and have been tilted to the left, which will increase the temperature range of powder mixture regeneration. From the curves related to the thermal differential analysis test, it can be seen that changes in the curves have occurred at temperatures of 400 , 700 , and $1000{ }^{\circ} \mathrm{C}$. These temperatures indicate the occurrence of a reaction and the creation of a new phase in the powder; these temperatures have been used for heat treatment.
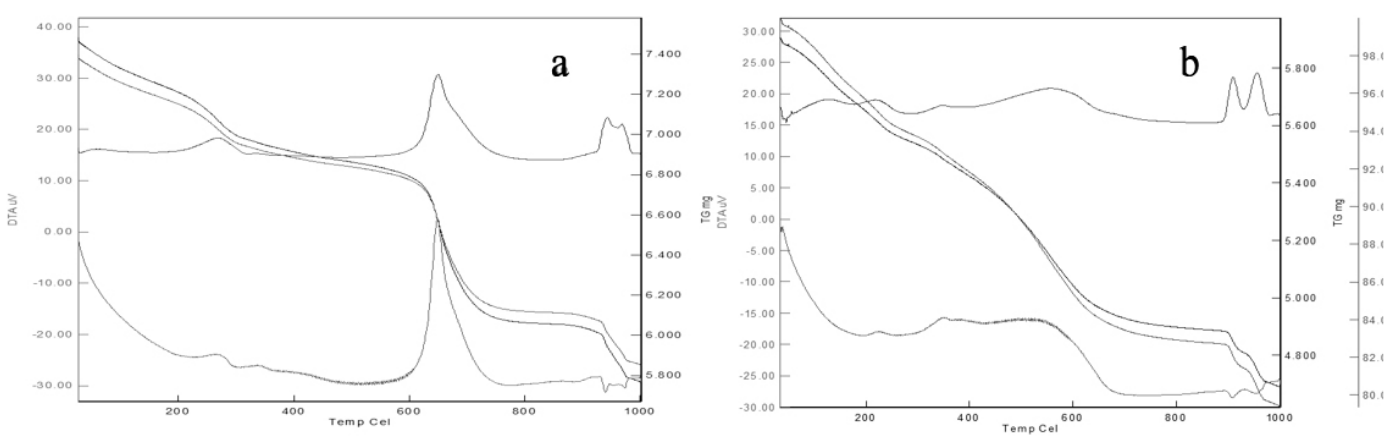

Figure 2. Curves for the differential thermal analysis test: (a) $10 \mathrm{~m}$ milled sample, (b) $10 \mathrm{~h}$ milled sample.

\subsection{SEM and Energy Dispersive X-ray Spectroscopy (EDS)}

Figure 3 shows SEM images of the sample after $30 \mathrm{~h}$ of milling that the particle size is small and the particle size distribution is narrow. Since the formed phase is oxidized and brittle, the workmanship causes more and more particles to be crushed and the particle size decreases, and the crushing rate is higher than the particle re-welding rate. 

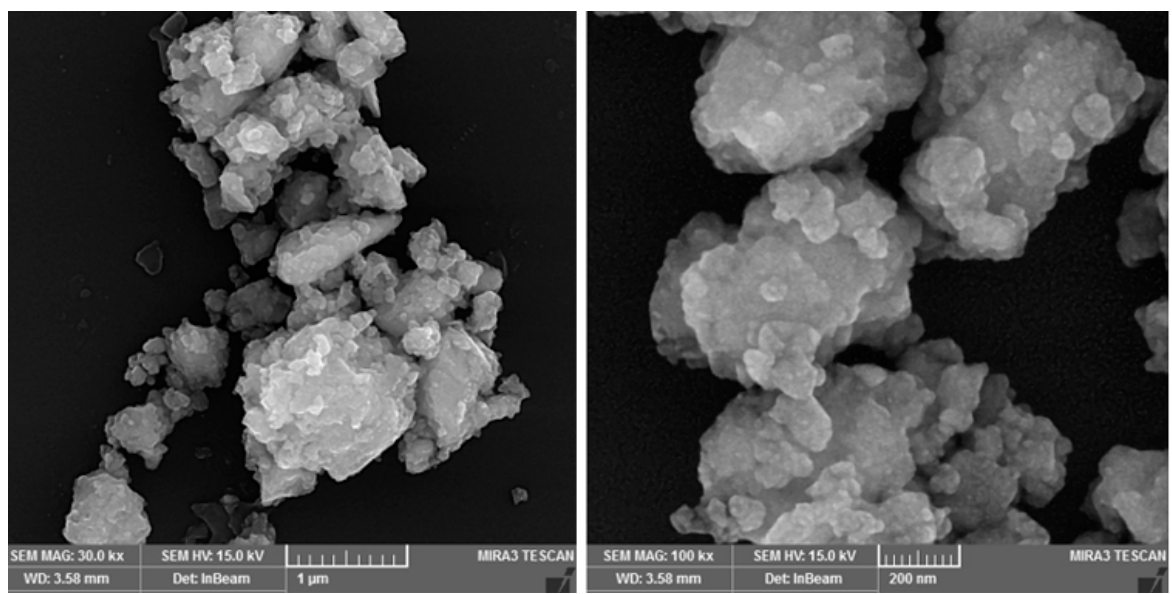

Figure 3. SEM images of the 30-h milled sample without heat treatment.

Table 4 shows SEM images After heat treatment at specific temperatures. The SEM images are sampled for $30 \mathrm{~h}$ milled sample and subsequently heat-treated at a temperature of 400,700 , and $1000{ }^{\circ} \mathrm{C}$ for one hour. According to these images, no significant growth has occurred due to the heat treatment at $400{ }^{\circ} \mathrm{C}$ due to the high melting temperature of the copper-tin alloy. However, heat treatment at $700{ }^{\circ} \mathrm{C}$ for one hour indicates that the fine particles of copper-tin alloy are partially formed. The fine particles attached to the alloy produced in the images are distinct. Thermal operations are performed at a temperature of $1000^{\circ} \mathrm{C}$ to completely form the copper-alkali alloy. The agglomerates in the structure are somewhat rare, due to the addition of polyethylene glycol surfactants to the powder mixture. Furthermore, a series of new phases have been formed at this temperature, and EDS analysis has been used to detect these phases.

Table 4. SEM images of the alloy at different temperatures.

\begin{tabular}{|c|c|c|}
\hline Temperature & SEM Images & Average Particles Size (nm) \\
\hline 400 & & $200-500$ \\
\hline 700 & & $500-900$ \\
\hline 1000 & & $500-800$ \\
\hline
\end{tabular}


Figure 4 shows the EDS analysis of the formed phases. Considering the presence of oxygen in the EDS analysis and the presence of copper and tin oxide phases in the X-ray diffraction pattern of the 30-h milled sample, it can be concluded that the dark-colored phases formed in the electron microscope images are related to copper oxides. The tin remains in the structure, which is dark in color due to its smaller atomic number. The iron phase is also seen in very small amounts, which is related to particles extracted from the wall of the milling chamber during the milling of powder particles. Also, in this analysis, the remaining oxide phases in the structure, including copper oxide and tin oxide and graphite, and the newly formed phases and some Fe, were completely identified, which are marked on the diagram.

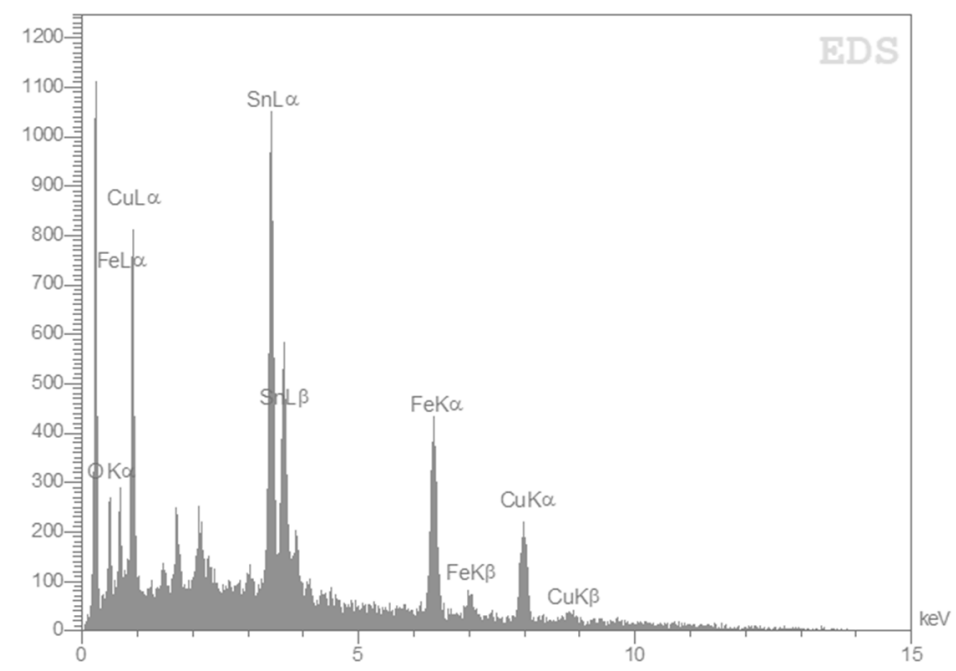

Figure 4. EDS analysis for the phases formed in Figure 3.

\subsection{Determining the Size of Crystals and Strain of Millwork Products and Heat Treatment}

Changes in crystal size and strain for milling products according to milling time using the Williamson-Hall method after correcting errors for milled products and heat treatment of Scherrer relationship due to the release of internal strains in the sample was calculated. Table 5 shows the average size of the crystals and the strained grid of the products obtained from the reduction.

Table 5. The average size of crystals and strain of products.

\begin{tabular}{ccccc}
\hline Strain (\%) & Crystals Size (nm) & Product & Thermal Operation Conditions & Milling Time \\
\hline 1.6 & 45 & $\mathrm{Cu}-\mathrm{Sn}$ & None & $10 \mathrm{~min}$ \\
1.7 & 25 & $\mathrm{Cu}-\mathrm{Sn}$ & $\mathrm{None}$ & $10 \mathrm{~h}$ \\
1.7 & 19 & $\mathrm{Cu}-\mathrm{Sn}$ & $400^{\circ} \mathrm{C}$ for one hour & $30 \mathrm{~h}$ \\
None & 19 & $\mathrm{Cu}-\mathrm{Sn}$ & $700^{\circ} \mathrm{C}$ for one hour & $30 \mathrm{~h}$ \\
None & 19 & $\mathrm{Cu}-\mathrm{Sn}$ & $1000^{\circ} \mathrm{C}$ for one hour & $30 \mathrm{~h}$ \\
\hline
\end{tabular}

Note: None in Table 5. mean There is no data exist.

Table 5 shows that with increasing temperature and milling time, the size of the produced powder crystals decreased to about $19 \mathrm{~nm}$. This decrease in particle size caused the strain to be affected and increased to $1.7 \%$. On the other hand, the table shows that heat treatment at temperatures of 400 , 700 , and $1000{ }^{\circ} \mathrm{C}$ has no effect on the strain percentage and crystal size, and these two parameters are affected by milling time. From the SEM images, it can be concluded that the size of the crystals has not changed in heat treatment, but the size of the particle or particle set has become larger. 


\subsection{Optical Density}

The effect of nanoparticles (copper-tin) on the bacteria studied in the environment: optical density test was performed with a wavelength of $600 \mathrm{~nm}$. Previous studies have shown that with changes in the concentration of tin precursor oxide and metal, there are no significant differences in the antibacterial properties of the alloy, and this experiment was performed with different concentrations of alloy powder. First, the sample with a concentration of $5 \mathrm{ppm}$ was considered as a control, then the concentrations of 10,50, and $100 \mathrm{ppm}$ of the produced nanopowder were added to the culture medium and tested for $10 \mathrm{~h}$. Figure 5 shows increasing the concentration of nanoparticles, the bactericidal property increases and the graph tends to zero. Over time, the graph gradually moves upwards by $10 \mathrm{~h}$. It shows that the antibacterial properties of the nanopowder have been reduced and that the bacteria are dominating the growth medium.

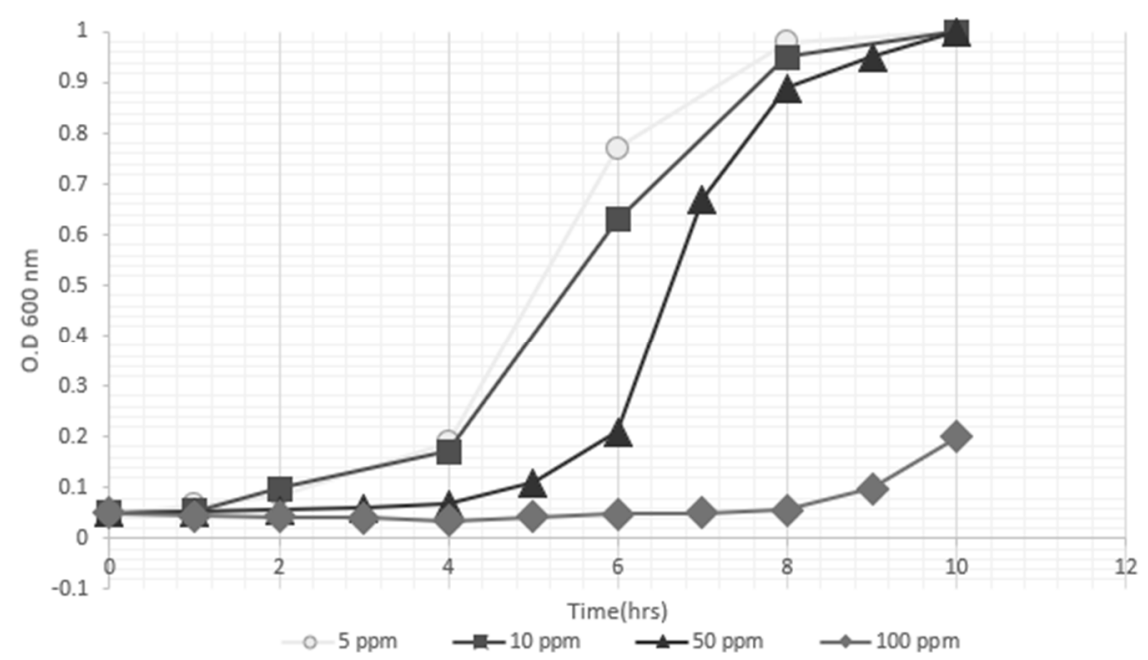

Figure 5. Optical density diagram at concentrations of 5, 10, 50, and $100 \mu \mathrm{mol} / \mathrm{L}$ with $\mathrm{Cu}-17 \mathrm{Sn}$ alloy in the bacterial culture medium.

In the case of concentrations of 10 and $50 \mathrm{ppm}$, it can be noted that the changes are almost the same, but in the concentration of $100 \mathrm{ppm}$, antibacterial properties are more pronounced, and the graph has moved downwards. This diagram for the alloy produced with copper and tin alloy produced from raw materials of pure copper and tin is also reported in the same way, which shows that the antibacterial properties of the produced alloys do not differ much, except in the alloy produced with oxide of copper and oxide of tin alloy production. From the raw materials of copper oxide, tin oxide, and carbon, better antibacterial properties were observed.

As shown in the diagrams, Figure 6 shows the optical density of the copper with increasing the amount of copper in the produced alloy, and, will see the most desirable bactericidal properties of the alloy produced. In Figure 6, the control samples are compared with each other, the same result is shown in Figure 7. Samples containing $10 \mathrm{ppm}$ of the produced alloy are shown, and the $\mathrm{Sn}-83 \mathrm{Cu}$ alloy has shown a desirable property, and it has reached $50 \mathrm{ppm}$, which still has the desired property in the alloy containing the highest percentage of copper. 

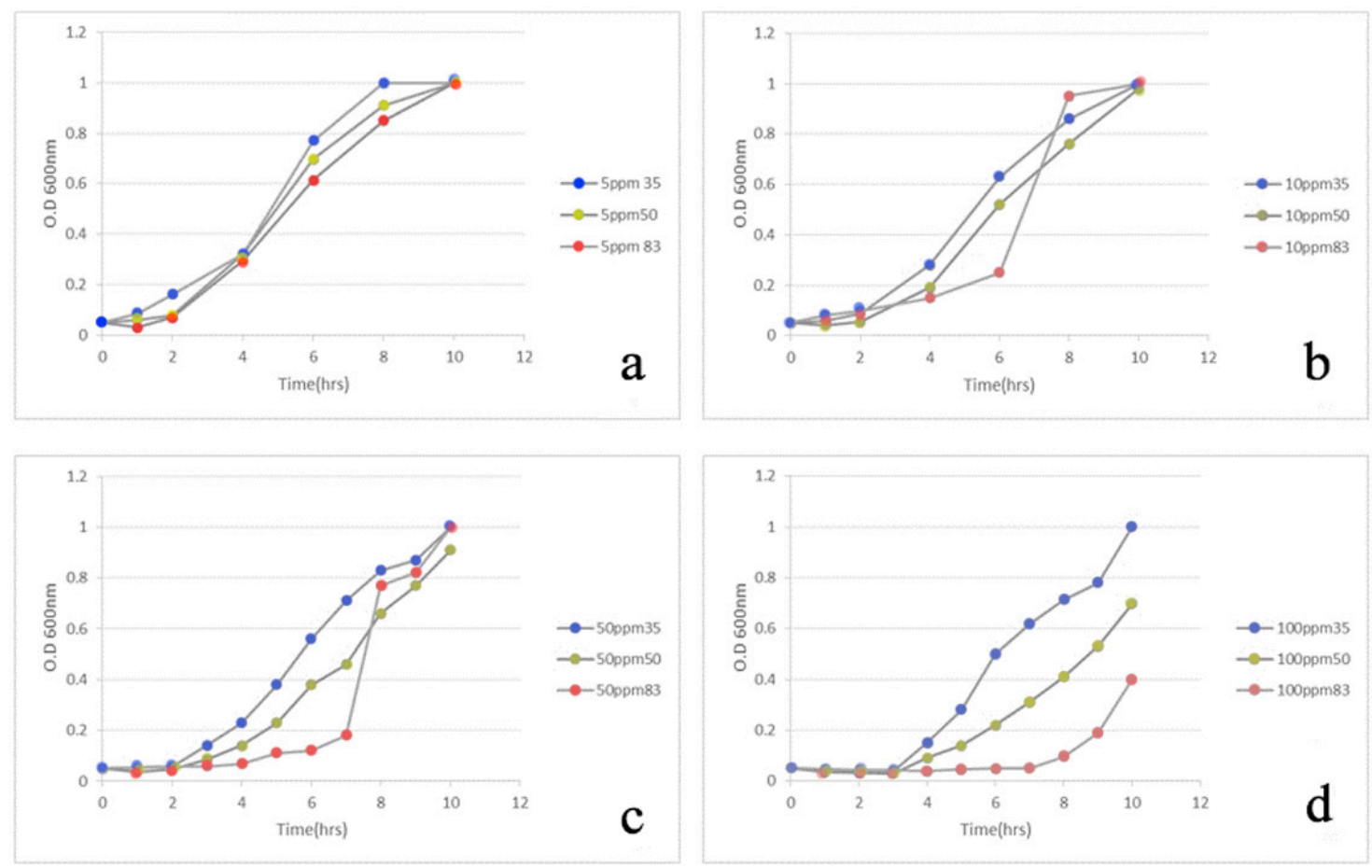

Figure 6. Comparative diagram of optical density overtime at concentrations of (a) 5, (b) 10, (c) 50, and (d) $100 \mu \mathrm{mol} / \mathrm{L}$ of the sample produced from the raw materials of copper oxide and tin oxide examined separately.

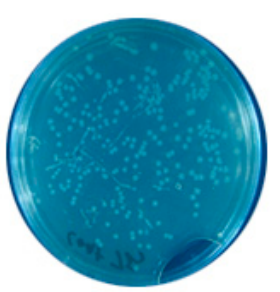

a) $2 \mathrm{mg}$

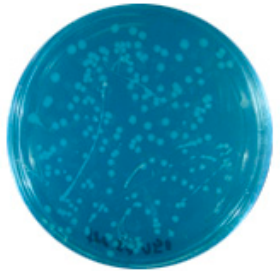

b) $2.75 \mathrm{mg}$

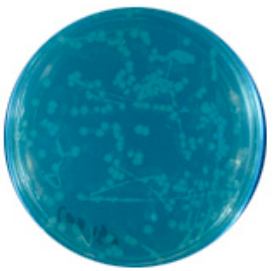

c) $3.5 \mathrm{mg}$

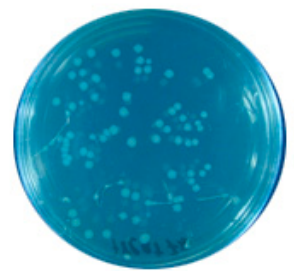

d) $4.5 \mathrm{mg}$

Figure 7. Colonies of Escherichia coli in liquid environment related to 50\% copper and 50\% tin alloy in different concentrations of copper-tin powder; (a) $2 \mathrm{mg}$ (b) $2.75 \mathrm{mg}$ (c) $3.5 \mathrm{mg}$ (d) $4.5 \mathrm{mg}$.

According to the statistical analysis of the optical density of the spectrum of treatment environments, it was found that the concentration of $100 \mathrm{ppm} \mathrm{Cu-Sn} \mathrm{nanoparticle} \mathrm{in} \mathrm{bacteria} \mathrm{was} \mathrm{destroyed} \mathrm{by} \mathrm{more}$ than $80 \%$. Similarly, as the concentration of $\mathrm{Cu}-\mathrm{Sn}$ nanoparticles increases, the effect of side bacteria increases. At a concentration of $50 \mathrm{ppm}$, the lethality of $\mathrm{Cu}-\mathrm{Sn}$ nanoparticles was 65\% compared to the control group in Escherichia bacteria. Also, $\mathrm{Cu}-\mathrm{Sn}$ nanoparticles at a concentration of 10 ppm were able to remove $40 \%$ of Escherichia bacteria.

As shown in Figure 6, the mechanical alloys of copper and tin in 35\%, 50\%, and 83\% of copper have been tested for optical density: (a) corresponds to $5 \mathrm{ppm}$, which is considered as a control sample and all three curves intersect in $4 \mathrm{~h}$; (b) corresponds to $10 \mathrm{ppm}$, which has been determined after comparison that, in addition to the relative effect on the bacteria, they completely kill the bacteria within $8 \mathrm{~h}$; (c) corresponds to a concentration of $50 \mathrm{ppm}$. The curves are separated from each other, which indicates the interference between time and the destruction of bacteria; finally, (d) is related to 100 ppm curves in which all bacteria are destroyed after $10 \mathrm{~h}$.

Overall, copper-tin nanoparticles had a greater effect on the Escherichia bacterium, and, the mechanism of action of copper-tin is similar to that of other nanoparticles, but it works more by destroying the bacterial wall. 


\subsection{Colony Forming Units Counting}

Another test used in this study is CFU. The bacterium used in this research is the famous bacterium Escherichia coli, which has many research applications, but there are two ways to count colonies: one is the traditional method of manual calculation, which is done with a chessboard, and the other is the method of using the colony counter, which is the second method used in this study.

Nanocrystalline powder concentrations were added to the culture media and images were taken from these media, which clearly showed that the bactericidal properties were increased by adding the powder at higher concentrations. After viewing the optical density test charts and discussing the results of these charts, it will eventually lead to the fact that these charts are complementary to the CFU bacterium and are not only studied as an antibacterial test but should also be combined with another test. For this purpose, CFU bacteria were studied and the results can be seen in the images below.

Figure 7 shows that the generated $\mathrm{Sn}-50 \mathrm{Cu}$ alloy has antibacterial or bactericidal properties, but this property is much lower than the $\mathrm{Sn}-83 \mathrm{Cu}$ sample. These images show that with the increase in the amount of hot alloy powder produced in the culture medium, the number of colonies decreased; however, this decrease was very small, and compared to the $\mathrm{Sn}-83 \mathrm{Cu}$ sample, it would have less bactericidal properties. Increasing the amount of alloy powder produced in the culture medium from 0.25 to $2 \mathrm{mg}$ has similar results, and only by increasing the values more than the alloy powder produced in the environment can we see a change in the number of colonies. This increase in concentration continued up to $4.5 \mathrm{mg}$, which is not more acceptable in terms of colony counting test standards and is the final limit for adding alloy powder produced to the culture medium. Adding this amount to the culture medium shows that the powder produced has antibacterial properties because the number of colonies decreases, but the main point is that this has less bactericidal properties compared to $\mathrm{Sn}-83 \mathrm{Cu}$ powder produced.

Figure 8 shows that the $\mathrm{Sn}-83 \mathrm{Cu}$ sample has a very good bactericidal property. From the analysis of images and counting of colonies, it is clear that by increasing the concentration of milligrams of produced alloy powder $\mathrm{Sn}-83 \mathrm{Cu}$ to the bacterial growth medium, in this environment, the number of bacterial colonies is rapidly reduced, which indicates the optimal bactericidal properties of the alloy produced. Compared to the bactericidal properties of the $\mathrm{Sn}-50 \mathrm{Cu}$ alloy sample, this property is much higher, so that by increasing $2.75 \mathrm{mg}$ of $\mathrm{Sn}-83 \mathrm{Cu}$ powder produced, the bacterial culture medium will be free of any bacteria, which is this amount compared to the $\mathrm{Sn}-50 \mathrm{Cu}$ sample. It is much less because in the Sn-50Cu sample, even with the addition of $4.5 \mathrm{mg}$ of the produced alloy powder, it still did not show the desired property, but in the case of the Sn-83Cu sample, only $2.75 \mathrm{mg}$ of the produced powder was observed. The bactericidal property is very good and in the bacterial culture medium, it is almost impossible to find the bacterial colony.

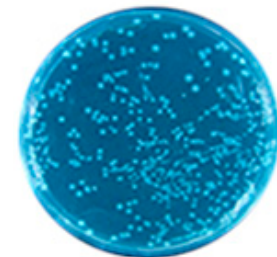

a) Without NPs

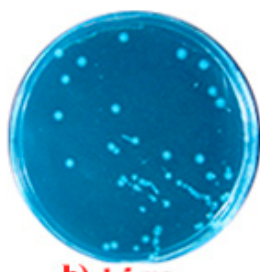

b) $1.5 \mathrm{mg}$

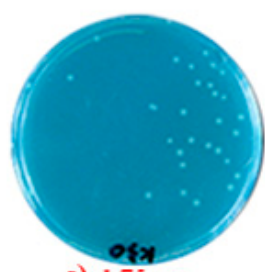

c) $1.75 \mathrm{mg}$

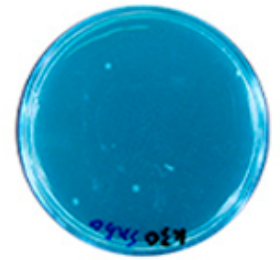

d) $2.5 \mathrm{mg}$

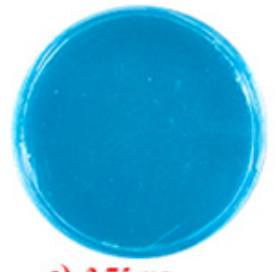

e) $2.75 \mathrm{mg}$

Figure 8. Colonies of Escherichia coli in liquid environment related to $83 \%$ copper and $17 \%$ tin alloy in different concentrations of copper-tin powder; (a) without nanoparticles (b) $1.5 \mathrm{mg}$ (c) $1.75 \mathrm{mg}$ (d) $2.5 \mathrm{mg}$ (e) $2.75 \mathrm{mg}$.

In general, in the clone counting test, samples containing 50\% copper and $50 \%$ tin and $83 \%$ copper and $17 \%$ tin samples were used. It was observed that in the $\mathrm{Sn}-50 \mathrm{Cu}$ sample, with increasing concentrations of 2, 75, 2, 3.5, and $4.5 \mathrm{mg}$, respectively, the number of bacterial colonies decreased and the size of the Escherichia coli bacterial growth medium decreased, but their size was significant. The idea behind this test is that more powder should be added to the environment than the bactericidal 
property. This means that for alloy $50 \%$ copper and $50 \%$ tin, by adding $4.5 \mathrm{mg}$ of alloy powder, we will achieve the desired properties, while if using $\mathrm{Sn}-83 \mathrm{Cu}$, only $2.75 \mathrm{mg}$ of this alloy can kill all bacteria in the culture medium, which proves that with increasing copper content, the bactericidal properties of the alloy will increase to the point where the other medium is completely It is free of bacteria. To count the existing colonies and to calculate the pour plate method, about $15 \mathrm{CC}$ of the nutrition agar medium was poured into each plate. The culture medium temperature should not be high to kill microorganisms, approximately 45 to $50{ }^{\circ} \mathrm{C}$ is the best condition. The plates were rotated five times to make the solution uniform. Then they are placed motionless. Tiles must be marked, which include dilution, group, hour, and day. In this experiment, about eight samples were examined. The plate was placed in a $32{ }^{\circ} \mathrm{C}$ incubator for $48 \mathrm{~h}$ and counted after the colonies had grown. as shown in Table 6, the number of colonies has decreased with increasing concentrations of nanoparticles in the culture medium.

Table 6. The number of colonies created in each sample of the pour plate method.

\begin{tabular}{ccccccccc}
\hline Sample Number & $\mathbf{1}$ & $\mathbf{2}$ & $\mathbf{3}$ & $\mathbf{4}$ & $\mathbf{5}$ & $\mathbf{6}$ & $\mathbf{7}$ & $\mathbf{8}$ \\
\hline $\begin{array}{c}\text { Number of colonies } \\
\text { Average }\end{array}$ & $>300$ & $>300$ & $>300$ & 296 & 225 & 89 & 9 & 6 \\
\hline & $89+225+296=610$ & & & $610 / 3=203$ & \\
\hline
\end{tabular}

\section{Conclusions}

In general, the results of the present study prove several issues:

1-Metal nanoparticles have very effective antibacterial properties.

2-The results obtained from determining the antibacterial properties of copper-tin nanoparticles showed that between the concentration of nanoparticles and the percentage of removal of bacteria are directly related.

3-The effect of colloidal nanoparticles on these bacteria is lethal and not inhibitory.

4-The solution of colloidal nanoparticles is released as microscopic particles and can easily penetrate to bacterial cells.

5- $\mathrm{CuO}$ and $\mathrm{SnO}_{2}$ nanoparticles can be used to treat infections and diseases caused by Escherichia coli based on the biological effects of nanoparticles.

6-The results of the optical density test show that the bactericidal property increases with increasing the concentration of nanopowder produced in the bacterial culture medium.

7-The results of the bacterial counting test fully confirm the results of the optical density test and show that increasing the concentration of nanopowder produced in the bacterial culture medium increases the bactericidal property.

8-According to observations, no changes will occur with the addition of more than $4.5 \mathrm{mg}$ of $\mathrm{Sn}-50 \mathrm{Cu}$ alloy to the culture medium, and no changes will occur with the addition of more than $2.75 \mathrm{mg}$ of $\mathrm{Sn}-83 \mathrm{Cu}$ alloy, indicating that more will be added. It is somewhat effective in the size of nanoparticles to the culture medium and will have no further effect.

Author Contributions: Conceptualization, M.S.Y. and M.T.N.; Data curation, M.R.; Formal analysis, M.R.; Investigation, M.R.; Methodology, M.S.Y.; Project administration, M.S.Y. and M.T.N.; Resources, M.R.; Supervision, M.S.Y. and M.T.N.; Visualization, M.R.; Writing—original draft, M.R.; Writing—review \& editing, M.R. and R.A. All authors have read and agreed to the published version of the manuscript.

Funding: This research received no external funding.

Conflicts of Interest: The authors declare no conflict of interest.

\section{References}

1. Zhang, L.; Jiang, Y.; Ding, Y.; Daskalakis, N.; Jeuken, L.; Povery, M.; O’Neil, A.J.; York, D.W. Mechanistic investigation into antibacterial behavior of suspensions of $\mathrm{ZnO}$ nanoparticles against E. coli. J. Nanopart. Res. 2009, 12, 1625-1636. [CrossRef] 
2. Menazea, A.A.; Ahmed, M.K. Silver and copper oxide nanoparticles-decorated graphene oxide via pulsed laser ablation technique: Preparation, characterization, and photoactivated antibacterial activity. Nano Struct. Nano Objects 2020, 22, 100464. [CrossRef]

3. Yu, B.; Leung, K.M.; Guo, Q.; Lau, W.M.; Yang, J. Synthesis of Ag-TiO2composite nano-thin film for antimicrobial application. Nanotechnology 2011, 22, 115603. [CrossRef] [PubMed]

4. Li, W.-R.; Xie, X.-B.; Shi, Q.-S.; Zeng, H.-Y.; Ou-Yang, Y.-S.; Chen, Y.-B. Antibacterial activity and mechanism of silver nanoparticles on Escherichia coli. Appl. Microbiol. Biotechnol. 2009, 85, 1115-1122. [CrossRef] [PubMed]

5. Chaudhary, A.K.; Vijayakumar, R.P. Effect of chemical treatment on biological degradation of high-density polyethylene (HDPE). Environ. Dev. Sustain. 2018, 22, 1093-1104. [CrossRef]

6. Dutta, R.K.; Nenavathu, B.P.; Gangishetty, M.K.; Reddy, A.V.R. Studies on antibacterial activity of ZnO nanoparticles by ROS induced lipid peroxidation. Colloids Surfaces B Biointerfaces 2012, 94, 143-150. [CrossRef] [PubMed]

7. Selvam, S.; Rajiv Gandhi, R.; Suresh, J.; Gowri, S.; Ravikumar, S.; Sundrarajan, M. Antibacterial effect of novel synthesized sulfated $\beta$-cyclodextrin crosslinked cotton fabric and its improved antibacterial activities with $\mathrm{ZnO}, \mathrm{TiO} 2$ and Ag nanoparticles coating. Int. J. Pharm. 2012, 434, 366-374. [CrossRef] [PubMed]

8. Ruparelia, J.P.; Chatterjee, A.K.; Duttagupta, S.P.; Mukherji, S. Strain specificity in antimicrobial activity of silver and copper nanoparticles. Acta Biomater. 2008, 4, 707-716. [CrossRef] [PubMed]

9. Navidinia, M.; Najar Peerayeh, S.; Fallah, F.; Bakhshi, B. Phylogenetic Groups and Pathogenicity Island Markers in Escherichia coli Isolated From Children. Jundishapur J. Microbiol. 2013, 6, 1U. [CrossRef]

10. Pawar, A.; Raut, A.; Kalrao, V.; Jacob, J.; Godha, I.; Thomas, R. Etiology and Clinical Outcomes of Neonatal and Pediatric Sepsis. Arch. Pediatr. Infect. Dis. 2016, 4, e33602. [CrossRef]

11. García-Sureda, L.; Juan, C.; Doménech-Sánchez, A.; Albertí, S. Role ofKlebsiella pneumoniaeLamB Porin in Antimicrobial Resistance. Antimicrob. Agents Chemother. 2011, 55, 1803-1805. [CrossRef] [PubMed]

12. Nordmann, P.; Naas, T.; Poirel, L. Global Spread of Carbapenemase-producing Enterobacteriaceae. Emerg. Infect. Dis. 2011, 17, 1791-1798. [CrossRef] [PubMed]

13. Luo, Y.; Yang, J.; Zhang, Y.; Ye, L.; Wang, L.; Guo, L. Prevalence of $\beta$-lactamases and 16S rRNA methylase genes amongst clinical Klebsiella pneumoniae isolates carrying plasmid-mediated quinolone resistance determinants. Int. J. Antimicrob. Agents 2011, 37, 352-355. [CrossRef] [PubMed]

14. Melia, S.; Novia, D.; Juliyarsi, I. Antioxidant and Antimicrobial Activities of Gambir (Uncaria gambir Roxb) Extracts and Their Application in Rendang. Pakistan J. Nutr. 2015, 14, 938-941. [CrossRef]

15. Jianxin, W. Effect of the content of ball-milled expanded graphite on the bending and tribological properties of copper-graphite composites. Mater. Des. 2013, 47, 667-671.

16. Kang, Y. Controlling the antibacterial activity of CuSn thin films by varying the contents of Sn. Appl. Surf. Sci. 2016, 389, 1012-1016. [CrossRef]

17. Tu, K.N. Cu/Sn interfacial reactions: Thin-film case versus bulk case. Mater. Chem. Phys. 1996, 46, $217-223$. [CrossRef]

(C) 2020 by the authors. Licensee MDPI, Basel, Switzerland. This article is an open access article distributed under the terms and conditions of the Creative Commons Attribution (CC BY) license (http://creativecommons.org/licenses/by/4.0/). 